\title{
TECHNOLOGY IN TEACHING SPEAKING SKILL
}

\author{
Dewi Sri Kuning \\ STKIP MUHAMMADIYAH KOTA BUMI, Lampung \\ dewisrikuning@gmail.com
}

\begin{abstract}
Berbicara merupakan salah satu kemampuan yang harus dimiliki oleh siswa dalam belajar bahasa Inggris, karena berbicara digunakan sebagai alat untuk berkomunikasi satu dengan yang lainnya. Pada abad ke-21 ini, banyak sekali inovasi pembelajaran yang diperkenalkan sebagai alat untuk belajar berbicara, salah satunya adalah teknologi modern. Dalam pembelajaran, banyak jenis teknologi modern yang diperkenalkan untuk membantu siswa dalam belajar berbicara, seperti laboraturium bahasa, video, satelit, internet, blog, kamus digital, dan lainnya. Teknologi modern tersebut bertujuan untuk meningkatkan kemampuan siswa dalam berbicara terutama berbicara bahasa Inggris.
\end{abstract}

KEYWORDS: Modern Technologies, Teaching Speaking Skill.

\section{INTRODUCTION}

English language has become an international language. Among nations it serves as a lingua franca. It is spoken, learnt and understood even in those countries where it is not a native's language. English is playing a major role in many sectors including medicine, engineering, education, advanced studies, business, technology, banking, computing, tourism, and so on. All our software development today, the communication facilities available to us through internet, our access to a variety of websites, are all being carried out in English. Most of the research works are conducted and compiled in English. Anything written and recorded in this language is read and listened to, in wider circles. As a result, English is being taught and learned around the world as a second language today.

From all four key language skills, speaking is deemed to be the most important in learning a second or foreign language. As stated by Ur (1996), speaking included all other skills of knowing that language. Speaking is "the 
process of building and sharing meaning through the use of verbal and non-verbal symbols, in a variety of contexts" (Chaney, 1998). Speaking is a crucial part of second language learning and teaching, it's an art of communications and one of 4 productive skills, that must mastered in learning foreign language. Speaking a language is especially difficult for foreign language learners because effective oral communication requires the ability to use the language appropriately in social interactions (Shumin: 2002). Good speaking skills are the act of generating words that can be understood by listeners. According to Brown and Yule (1983), speaking is the skill that the students will be judged upon most in real-life situations. It is an important part of everyday interaction and most often the first impression of a person is based on his/her ability to speak fluently and comprehensively. So, teachers have a responsibility to prepare the students as much as possible to be able to speak in English in the real world outside the classroom.

In the preliminary stage, teachers used tape recorders as a technological device to instruct the students, which later evolved as communication laboratory. The integration of technology into language teaching which was started in the early 1960s and 1970s, assisted teachers to teach second language learners how to speak in the best way possible. Every day teachers are getting access to some new technologies, which join hand with English teaching. As the conventional teaching method such as the chalk and talk method seems to be outdated, the modern technologies can be used as a supplement to the classroom teaching method to have a lively atmosphere in the classroom. It is the need of the hour to integrate modern technologies to upgrade the level of English teaching. The modern technologies relax the mind of the students to get into the subject with full involvement rather than a difficult task to do. New technologies in language learning by multiple intelligence and mixed abilities replace with old methods of teaching.

Technologies allow students to become more independent in the classroom. It ushers as a fundamental structural changes to achieving significant improvements in productivity. It is used to support teaching and learning. It also 
has the power to transform teaching by ushering in a new model of connected teaching.

\section{WHAT IS "TEACHING SPEAKING"?}

For many years, teaching speaking has been undervalued and English language teachers have continued to teach speaking just as a repetition of drills or memorization of dialogues. Today's world requires that the goal of teaching speaking should improve the students' communicative skills, because only that way the students can express themselves and learn how to follow the social and cultural rules appropriate in each communication circumstance.

Teaching speaking is to teach our learners to:

- $\quad$ Produce the English speech sounds and sound patterns.

- Use word and sentence stress, intonation patterns and the rhythm of the second language.

- Select appropriate words and sentences according to the proper social setting audience, situation and subject matter.

- Organize their thoughts in a meaningful and logical sequence.

- Use language as a means of expressing values and judgments.

- Use the language quickly and confidently with few unnatural pauses, which is called as fluency (Nunan, 2003).

\section{REASONS FOR TEACHING SPEAKING}

English become an International language in the world. So, all media, technologies, and all the things will use English. In Indonesia, English as the foreign language, because of that English will be thought for the students in Indonesia. Here some reasons about teaching speaking:

- Speaking is a crucial part of second language learning and teaching.

- The mastery of speaking skills in English is a priority for many second language or foreign language learners. 
- Our learners often evaluate their success in language learning as well as the effectiveness of their English course on the basis of how much they feel they have improved in their spoken language proficiency.

- Oral skills have hardly been neglected in today's EFL/ESL courses.

\section{THE ROLES OF STUDENTS IN LEARNING SPEAKING}

There are some categories that can be used as the role of learners in developing speaking skills in the classroom (Brown, 2001):

- Imitative - A very limited portion of classroom speaking time may legitimately be speech generating "human tape recorder speech, where, for example, learner practice an intonation contour or try to pinpoint a certain vowel sound. Imitation of this kind is carried out nit the purpose of meaningful interaction, but for focusing on some particular element of language form.

- Intensive - It goes one step beyond imitative to include any speaking performances that are designed to practice some phonological or grammatical aspects of language.

- Responsive - It consists of short replies to teacher-or student-initiated questions or comments.

- Transactional (dialogue) - Transactional language, carried out for the purposes of conveying or exchanging specific information, is an extended form of responsive language.

- Interpersonal (dialogue) - It carried out more the purpose of maintaining social relationships than for the transmission of a fact and information. These conversations are little trickier for learners because they can involve some or all of the following factors - a casual register, colloquial language, emotionally charged language, slang and sarcasm.

- Extensive (monolog) - Here the register is more formal and deliberative. It can be planned or impromptu. Students at intermediate to advanced levels are called on to give extended monologues in the form of oral reports summaries of perhaps short speeches. 


\section{MODERN TECHNOLOGIES IN DEVELOPING SPEAKING SKILL}

In the fast developing 21 st century various innovative technologies are being introduced to teach English in the classrooms. Knowledge base is fast doubling and tripling in so short a time. To cope up with this trend, we have to use modern technologies to teach English to the technical students. Technology can stimulate the playfulness of learners and immerse them in a variety of scenarios.

Technology gives learners a chance to engage in self-directed actions, opportunities for self-paced interactions, privacy, and a safe environment in which errors get corrected and specific feedback is given. Studies are emerging that show the importance of qualitative feedback in software. When links are provided to locate explanations, additional help, and reference, the value of technology is further augmented. The moderntechnologies relax the mind of the students to get into the subject with full involvement rather than a difficult task to do.

Modern technologies available for teachers of English today are:

- Communication lab

- Video conferencing

- Video Library

- CALL (Computer Assisted Language Learning)

- TELL (Technology Enhanced Language Learning)

- Pod casting

- Quick Link Pen

- Quicktionary

- Programmes through educational satellites

- Speech Recognition Software

- Internet

- Blogging 


\section{HOW TO USE THESE TECHNOLOGIES:}

\section{Communication Labs}

Software's are available to develop speaking skills. By incorporating suitable software through computers the students will play it again and again with their own interest and try to improve their speaking skills, which are most essential in this modernized IT world. The usage of headphones in the lab makes the students to have interest over the subject and induces them to repeat again and again instead of feeling boredom.

\section{Video Conferencing}

Video conferencing is the method in which one person can access to the speeches of other persons in some other parts of the world. It is the live relay of a programme, which is mostly used to view the lecture of a professor who resides in foreign country. In short it is very helpful for the students to understand what is going in this world and to hear the speech of the top most personalities in a lively manner. The most notable point in video conferencing is that the students can post questions immediately and get their answers at once.

\section{Video Library}

Video Libraries are most essential in our fast and modernized world. This is helpful for the students to those who miss some interesting session. In this process the teaching of the faculty will be recorded and made available to the students. The students can view the tapes in their leisure hours. The advantage in this method is that students can replay it when there is a necessity.

\section{CALL}

The educational role of Computers in learning a second language and the role of CALL (Computer Assisted Language Learning) is significant. The teacher can use the latest technologies, which have the potential to transform the students from passive recipients of information into active participants. CALL is defined as the search for and study of applications of the Computer in language teaching and learning.

\section{TELL}


TELL (Technology Enhanced Language Learning) is the use of computer technology including hardware, software and the internet to enhance teaching and learning of languages. It allows the students to get access with all the technologies available for the enhancement of English learning. Students are allowed to use online dictionaries, chat, and to view the various happenings around the world.

\section{Pod Casting}

Podcasts can be uploaded or downloaded, this audio help the learner familiarize with the target language and teachers can use them as useful audio material that can be used in class for activities like discussions, besides, in the web, there are even particular podcasts that are for ESL learners and these can include pronunciation for particular needs of students. Podcast undoubtedly help learners in speaking. Pod casting is the integration of audio files where we can feed our own materials and ply it inside and outside of the classroom. Students use i-pods to hear their favorite music files. In the same way they have their education in the form of entertainment.

Podcasting allows students to use their tech-based entertainment systems for educational purposes. With it we are able to move away from the traditional face-to-face training without losing the student-to-trainer relationship that is so effective in any learning process. Podcasts enables students and teachers to share information with anyone at anytime. An absent student can download the podcast of recorded lesson and is able to access the missed lectures. They could also access lectures of experts which may not otherwise be available because of geographical distance and other reasons.

\section{Quick Link Pen}

Quick Link Pen allows learners to copy and store printed text, Internet links. It helps to transfer the data to computers and enables the reader to get the meaning of the word from a built in dictionary. Accessing this type of machine seems to be a more convenient method. Recent developments in machine translations presents translation engines like GO Translator and Bablefish. 


\section{Quicktionary}

It is a pen-like device. It allows the reader to easily scan the word and get its definition and translation on its own LCD screen. Technology such as Enounce and Sound-Editor enable learners to adjust the speech rate of listening materials to assist their comprehension, and present spectrum of speech waves and visual depictions of mouth and tongue movement to ease the learning and refine pronunciation.

\section{Educational Satellites}

In the college we can create Educational Satellite lab, whereby satellite programs of educational value like $\mathrm{UGC}^{\text {ee }} \mathrm{s}$ country wide classrooms, Anna University programmes and other world wide programmes are recorded and students are given access to the recording either through big screen or small monitor.

\section{Speech Recognition Software}

Speech recognition software also helps improving the students speaking, this can convert spoken words to machine-readable input. The device recognizes the accuracy of what was read and then provides a positive reinforcement like "You sound great!" or gives the user an opportunity to try again, in this way the learner can figure if he is reading well or not. As the user's skill improves, the technology reads less material so that the learner reads more. This software also evaluates and provides scores of grammar, pronunciation, comprehension and provided with the correct forms, for examples if a student mispronounces a word, the learning tool can immediately spot it and help correct it. This device can be a very useful device for distance learners because they don't have a teacher who corrects their speech and this device can help improving their speaking skills.

\section{Internet}

Internet is a commonly acknowledged term and widely used by people throughout the world. Students now use Internet in the class to learn English. Online teaching inside the classroom seems to be interesting and makes the students to find out the suitable materials for them. Students are instructed to do the grammar exercises which are available online. Through Internet we can 
collect data from various sources for any instruction. to improve speaking, students can use Skype, MSM Messenger, Google talk (used to have conferences on line) and other applications where students can connect with friends, other students, teacher and even native speakers, these ways of learning have been observed to improve oral proficiency in students and make up for the lack of native speakers in the areas where students live and what is more, on line conferences also enhance intercultural awareness, motivation and raise the level of interaction. Over the internet, students can find a lot of learning materials, for instance, audio, video, radio and TV shows, games, voice recordings, quizzes, podcasts and so on, in this way, students get exposed to a great amount of target language and this help them develop their speaking skills.

\section{Blogging}

Blogging can be used for instructing the candidates when the teacher is off campus. The teacher can post his article or the instruction to the students, where the students are allowed to post their comments and queries. The teacher can answer the question through his blog. Blogging seems to be widely in use.

\section{CONCLUSIONS AND RECOMMENDATIONS}

The modern tools are in addition to the inputs given by the teachers in the classrooms. The technology helps the students to enhance their language learning in a fruitful way. Using technology in learning a second language has become a real necessity nowadays. Different methods for using technology in improving speaking skill were discussed thoroughly. As a result, the following concluding remarks and recommendations can be recorded:

- Modern technological tools are much more interesting and provide fun and enjoyable learning, motivating the students, and help them to enhance their language learning in a fruitful way, moreover, these tools help students learn at their own pace and promote autonomy in them.

- As technology has developed the incorporation of this medium into the instruction process become necessary. 
- Modern technical ways should be followed for effective learning and teaching of the speaking skill.

- English language teachers should encourage their students to use technology in developing their speaking skill.

- The computer is being viewed more as an integral part of the learning activity, and as a means by which skills are transferred to learners.

- Theory and practice in second language learning can be matched together by the use of modern technology.

- Educational institutions should modernize their technical instruction capabilities by using new equipments and laboratories for supporting the teaching process.

\section{REFERENCES}

Bahadorfan, Maryam and Reza Omidvar. 2014. Technology in Teaching Speaking Skill. Vol. II (IV) 9-13. Available on https://www.researchgate.net/publication/315790125 (Agustus 2018).

Brown, G. and G. Yule. (1983). Teaching the Spoken Language. Cambridge: Cambridge University Press.

Brown H. D. 2001. Principle of Language Learning And Teaching . New York : Prentice Hall.

Chaney, A.L., and T.L. Burk. (1998). Teaching Oral Communication in Grades $K-8$. Boston:Allyn\&Bacon.

Ganesan, S., and Shalini, R. 2011. Use of Modern Technologies to Teach Communication Skills. Vol. I (I). Available on https://sites.google.com/site/journaloftechnologyforelt/archive/january201 1/useofmoderntechnologiestoteachcommunicationskills (Agustus 2018).

Kang Shumin In Jack Richards C. and Willy A. Renandya. 2002. Methodology In Language Teaching. USA: Cambrige University Press.

Nunan, D. (2003). Practical English Language Teaching Teacher's Text Book. McGraw-Hill

Ur, P. (1996). A Course in Language Teaching, Practice and Theory. Cambridge University Press. 